\title{
The Impact of Oil Shock on Domestic Economy: The Case of Indonesia
}

\author{
Rossanto Dwi Handoyo ${ }^{1}$, Fadhlillah Aji Wibowo' ${ }^{2}$ Miguel Esquivias Padilla ${ }^{3}$, \\ Abdul Rahim Ridzuan ${ }^{4}$, Mohamad Idham Md Razak ${ }^{5}$ \\ ${ }^{1}$ Faculty of Economics and Business, Universitas Airlangga, Indonesia, \\ ${ }^{1}$ E-mail: Rossanto_dh@feb.unair.ac.id, ${ }^{2}$ E-mail: fadhlillah29@gmail.com, ${ }^{3} E$-mail: miguel@feb.unair.ac.id \\ ${ }^{4,5}$ Faculty of Business and Management, Universiti Teknologi MARA, Melaka Campus, Malaysia, \\ ${ }^{4}$ E-mail: Rahim670@staf.uitm.edu.my, ${ }^{5}$ E-mail: iedham@warga.uitm.edu.my
}

\begin{tabular}{|c|c|c|}
\hline Abstract & \multicolumn{2}{|c|}{$\begin{array}{l}\text { This study analyzes the impact of the world oil prices shock on Indonesia's domestic economy using a } \\
\text { Structural Vector Autoregression (SVAR) model. The variables used are divided into two groups. The first } \\
\text { group describes the world oil market, including world oil production, world economic activity, and world oil } \\
\text { prices. The second group describes the domestic economy comprising variables of GDP, CPI, discount rate and } \\
\text { rupiah exchange rate. The use of this model can remove impulse response anomalies or puzzle such as price } \\
\text { puzzles and exchange rate puzzles that are commonly found in studies that use VARs model in small open } \\
\text { economy countries. Estimation results show that the shock of world oil prices significantly affects the } \\
\text { domestic economy. The impulse response results show that the shock caused by world oil prices responded } \\
\text { differently at the beginning of the period but returned to the balance line in the long run. }\end{array}$} \\
\hline Key words & \multicolumn{2}{|c|}{ Shock, Impulse Response, Puzzle, Domestic Economy, SVA } \\
\hline Received: & 04 Apr 2020 & (C) The Authors 2020 \\
\hline Revised: & 09 May 2020 & Published by Human Resource Management Academic Research Society (www.hrmars.com) \\
\hline $\begin{array}{l}\text { Accepted: } \\
\text { ublished Online: }\end{array}$ & $\begin{array}{l}13 \text { May } 2020 \\
19 \text { May } 2020\end{array}$ & $\begin{array}{l}\text { This article is published under the Creative Commons Attribution (CC BY } 4.0 \text { ) license. Anyone may } \\
\text { reproduce, distribute, translate and create derivative works of this article (for both commercial and } \\
\text { non-commercial purposes), subject to full attribution to the original publication and authors. The full } \\
\text { terms of this license may be seen at: http://creativecommons.org/licences/by/4.0/legalcode }\end{array}$ \\
\hline
\end{tabular}

\section{Introduction}

The oil trade between countries in the world significantly affects the economy for both exporting and importing countries. The oil trade made using dollars often raises the question of oil prices to the domestic macroeconomy of a country. Changes in foreign factors significantly affect domestic economic and noneconomic performance for a country that embraces an open economic system. Small and open economies like Indonesia, the development of the domestic economy will be strongly influenced by factors from abroad, and its domestic economy cannot affect the world economy (Cunado et al., 2015).

Oil price shock is one of the factors abroad that is sometimes regarded as a variable affecting a country's economy. Research conducted by Hamilton (2003) mentions that there is a nonlinear relationship between oil prices and the economy.

Theoretically, the shaking of the world economy due to oil price shock affects macroeconomic activity through the demand side and supply side. The sharp increase in oil prices from the supply side will increase production costs in the oil-use sectors in the production process. An increase in input prices on production will result in the producers reducing their production to a certain amount. The decreasing total supply leads to a decrease in output and shifts the supply curve to the top left (Jimenez and Sanchez, 2005). 
The fluctuations shown in Figure 1 with the quarterly period below show the volatility of oil prices occurring in the first quarter of 1996 to 2014.

Many studies show the shock of oil prices followed by weakening world economic growth. Cunado et al. (2015) concluded that a good monetary policy through exchange rate policy could reduce the negative impact of oil price shocks on macroeconomics in Asian economies.

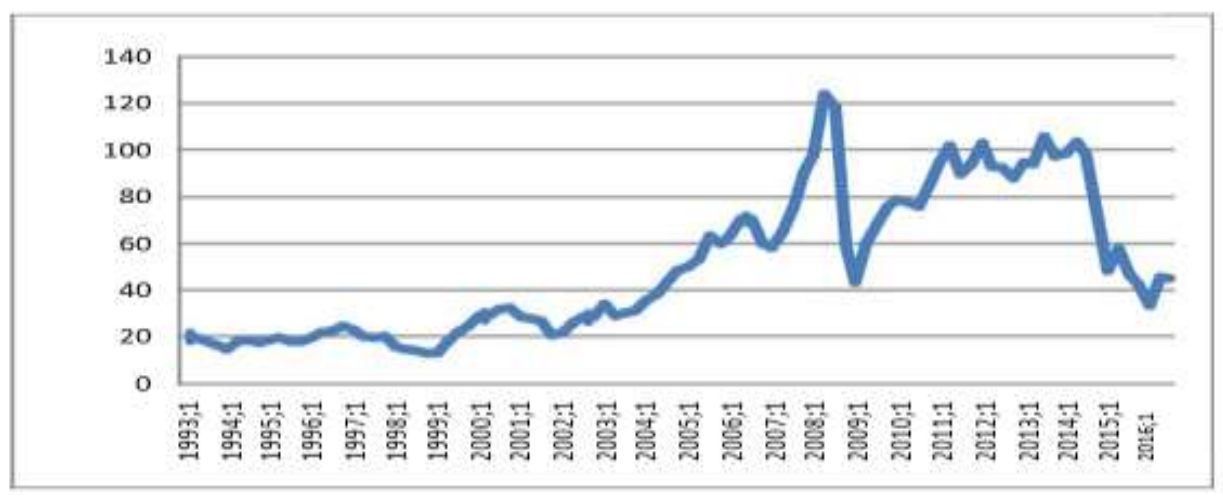

Figure 1. Fluctuations in World Oil Prices

The study by Rodriguez and Sanchez (2005) analyzes the relationship of oil shock to GDP in OECD countries. The study concluded the impact of shocks on oil prices on GDP. They also found that the impact of rising oil prices is greater than the fall in oil prices on GDP. The rise in oil prices has a negative impact on GDP among oil-importing countries, except for Japan. Oil importing countries are some countries that experience a negative impact from rising oil prices, and some experience a positive impact.

Shock oil prices result in an increased risk of macroeconomic instability that could disrupt the sustainability of economic growth. Changes in variable GDP, CPI, discount rate, and the exchange rate will affect the economy, both micro and macro. Changes in oil prices have consequences for economic fundamentals such as discount rates, price levels, and the balance of payments and employment opportunities that affect all those involved in the economy (Qing, 2004).

The development of Indonesian crude oil production and consumption can be seen in Figure 2 below.

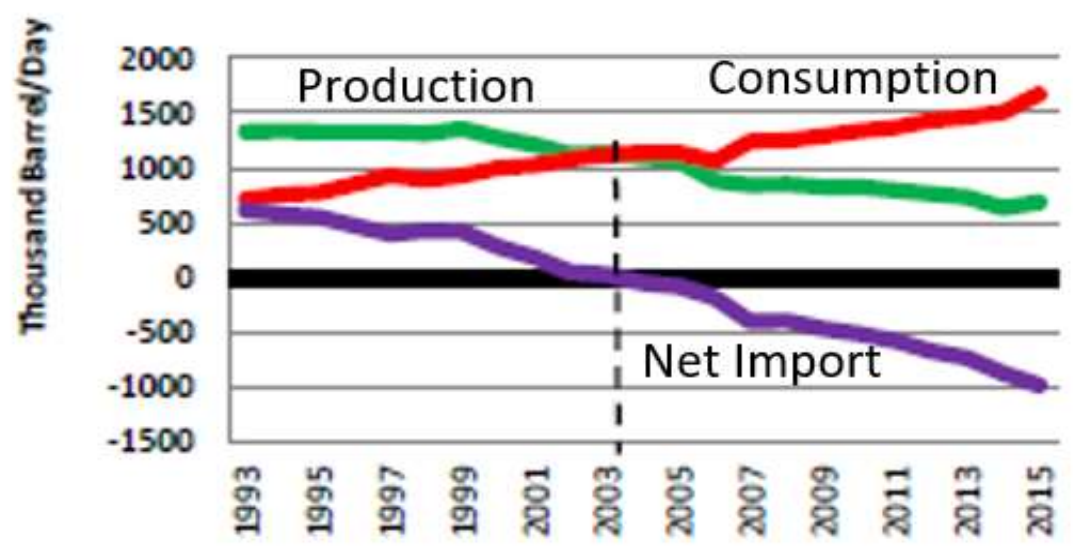

Figure 2. Indonesian Oil Production and Consumption

Since 2003 Indonesia's oil consumption has increased sustainably as a result of the consequences of economic expansion in the open economy. On the other hand, domestic crude oil production capacity did not increase along with the proportion of consumption increase. This resulted in Indonesia experiencing net deficit of oil imports. Data from the World Bank state Indonesia's oil consumption accounted for 46 per cent of total national energy consumption in 1980. They continued to increase so that in 2010 the ratio of oil consumption rose to 66 per cent of the total national energy consumption.

Empirical studies have been conducted and developed to examine the effect of oil prices on several macroeconomic variables of a country in the world. Given Indonesia's previous position as a net oil 
exporter, and turned into a net oil importer country in 2003, Indonesia experienced different effect in the transmission due to the shock of oil prices to macroeconomic variables. This study attempts to analyze the impact of oil price shock on domestic variables. Previous studies that have tested the impact of oil price shock on domestic variables have been widely used, for example, by Ichsandimas \& Cahyadin (2014) conducted in Indonesia using the VAR method. The author found a positive and significant relationship between oil prices with inflation and real GDP Indonesia but has a negative impact on the real exchange rate of Indonesia.

Buckle et al. (2007) examined the business cycle model on small open economy volatility using the SVAR method. The researchers divided 12 variables into four major groups of variables: climate, international linkages, terms of trade and commodity price influences and domestic economy. In the study, there was no impulse response anomaly (Puzzle). Usually, the VAR method that has been used in small open countries often occur anomaly on impulse response shock rate of the interest rate.

The first impulse response (puzzle) anomaly is the price puzzle. This anomaly is a condition in which the impulse response from the price level (CPI) to the shock of the discount rate shows a positive response. The second anomaly is the exchange rate puzzle is the state of impulse response from the exchange rate to shock discount rate indicates a positive response (depreciation) that should show a negative response (appreciation). This research tries to analyze the shock of oil price to macroeconomic variable in Indonesia country by using Structural Vector Autoregression (SVAR) model.

\section{Literature review}

The Mundell-Fleming model is an extension of the IS-LM model, developed to describe the economy in small open economy countries. This model shows an overview of the short-run relationship between the nominal exchange rate, interest rate, and output. The IS-LM model is similar to the Mundell-Fleming model. Both models are focused on the interaction between the product market and the money market. The assumption used by both models is that the price level is fixed. The special assumption used for the Mundell-Fleming model is the economy of the country studied by the small open economy with perfect capital mobility. This means that the country's economy can borrow and lend as much money as possible in world financial markets, so the country's interest rate is determined by world interest rates (Mankiw, 2009).

The specific assumptions of the Mundell-Fleming model in which domestic interest rates are equal to the world interest rates can be written mathematically: $r=r^{*}$

World interest rates are assumed exogenously fixed because the domestic economy is relatively small compared to the world economy so it can borrow or lend as much as possible to the world financial market without affecting world interest rates.

The Mundell-Fleming model describes the market of goods and services such as the IS-LM model, only adding net exports. The equations can be written:

$$
\mathrm{Y}=\mathrm{C}(\mathrm{Y}-\mathrm{T})+\mathrm{I}\left(\mathrm{r}^{*}\right)+\mathrm{G}+\mathrm{NX}(\mathrm{e})
$$

The equation represents aggregate output $(\mathrm{Y})$ is the total of consumption (C), investment (I), government spending (G), and net exports (NX). Consumption (C) is positively influenced by disposable income $(Y-T)$. Investment is negatively influenced by the interest rate $(r)$, according to the Mundell-Fleming model assumption that the domestic interest rate is equal to the world interest rate. Investment is negatively influenced by the world interest rate $\left(r^{*}\right)$. Net export (NX) is negatively affected by the exchange rate. i.e. the Mundell-Fleming Model also assumes that domestic and overseas prices are fixed so that the real exchange rate is proportional to the nominal exchange rate. This means that when domestic nominal exchange rate appreciates, foreign goods will become cheaper than domestic goods, and cause exports to fall and imports

The Mundell-Fleming model describes the financial markets with the equations of the IS-LM model using the specific assumptions $\left(r=r^{*}\right)$, which is:

$$
M / P=L\left(r^{*}, Y\right)
$$


This equation states that the real money supply (M/P) equals the demand of $L\left(r^{*}, Y\right)$. Demand for real money is negatively affected by world interest rates and positively by income $(\mathrm{Y})$. The price level $(\mathrm{P})$ on the Mundell-Fleming model is assumed to remain exogenously.

\subsection{Analysis model}

Econometrics method in this research using Structural Vector Auto-Regressive (SVAR) model. The specification of the model of analysis in this study was based on empirical models in research conducted by Cunado et al. (2015) using world oil production variables, oil prices in US dollars and world economic activity in international variable groups to capture changes in the world oil market.

To capture the movement of the domestic economy, there are variables of gross domestic product (GDP), consumer price index (CPI), the real exchange rate (RER), and discount rate.

The SVAR model is used in this paper because it can limit the relationship of variables based on structural equations that are built (non-recursive). In contrast to the VAR model, which generally restrictions on the relationship between variables does not occur because it is recursive. The analytical model used in this paper is based on empirical models in research conducted by Cunado et al. (2015); Baumeister et al. (2009) and Baumeister and Peersman (2010) as follows:

$$
\left[\begin{array}{l}
X_{t} \\
Y_{j, t}
\end{array}\right]=c+A(L)\left[\begin{array}{l}
X_{t-1} \\
Y_{j, t-1}
\end{array}\right]+B\left[\begin{array}{c}
\varepsilon_{t}^{X} \\
\varepsilon_{j, t}^{Y}
\end{array}\right]
$$

Where:

$X t$ is an international variable including Qoil, $Y w$, Poil; $Y j, t$ is a domestic economic variable including $\mathrm{GDP}, \mathrm{CPI}$, discount rate (i), an exchange rate (ER); $\mathrm{c}$ is a constant vector, $\mathrm{A}(\mathrm{L})$ is a polynomial matrix with lag operator $\mathrm{L}, \mathrm{B}$ is an Impact matrix of error term $\varepsilon \mathrm{tX}$ and $\varepsilon j, \mathrm{tY}$; $\varepsilon \mathrm{tX}$ denotes structural shock on international variables and $\varepsilon j$, tY shows shock to domestic variables.

\subsection{Variable identification}

In a study using Structural VAR, all variables were treated symmetrically regardless of dependent variables and independent variables (Enders, 2004). Based on the subject matter in this study, the variables analyzed are oil prices, world oil production, world economic activity, GDP, CPI, real exchange rate, discount rate.

World oil prices are the world's crude oil prices formed by the demand and supply of world oil commodities. World oil prices are calculated in US Dollar per barrel (1 barrel = 159 liters), using the average world oil price of WTI (West Texas Intermediate), adjusted to the prevailing rupiah exchange rate in each year to produce data in currency rupiah. Data of world oil price used in this research is quarter data of period 1993 Q1 - 2016 Q3 obtained by U.S. Energy Information Administration and transformed into logarithmic form into percent units.

World oil production is the number of crude oil produced worldwide in 1000 barrels per day. The data used in this study were obtained from the U.S. Energy Information Administration and transformed into logarithmic form into percent units.

The world economic activity in this study is projected with world production data, where there are large countries of oil users such as China, India and U.S. America. The use of this data is appropriate as used in Baumeister and Peersman's research (2010) obtained from the Organization for Economic Co-operation and Development (OECD) with index units and transformed into logarithms into percent units.

GDP is a description of the level of expenditure or total output of a country. The level of expenditure can be said as the ability to buy, while the total output is the supply side generated by the population of the country. GDP used in this study is GDP from the expenditure side in billion rupiahs and transformed into logarithmic form into percent units.

The Consumer Price Index is an index that measures the cost of purchasing a fixed group of goods and services in a market that represents consumer purchases (Dornbusch et al., 2008). The data in this study use CPI of Indonesia with the base year $2010=100$ obtained from OECD (Organization for Economic Co-Operation and Development) and transformed into logarithmic form into percent unit.

The discount rate in this study is projected to use the SBI rate data is securities issued by Bank Indonesia as recognition of short-term debt (1-3 months) with discount or interest system. The SBI rate is a 
mechanism used by Bank Indonesia to control the stability of the Rupiah. The data used is obtained from the central bank, namely Bank Indonesia, with per cent unit.

The exchange rate, according to Salvatore (2012), is defined as the price of the domestic currency unit against the foreign currency. In this study, the rupiah currency is set against the United States dollar (USD), the data used is the average nominal quarterly exchange rate derived from International Financial Statistics (IFS) and transformed into a form of the logarithm.

\subsection{Data}

This study uses secondary data in the form of quarterly time series (time series data with a quarterly period). The period of research data used is from 1993 Q1 to 2016 Q3 with the focus of the research are based on Indonesia, the United States and the world oil market. The data were obtained from Bank Indonesia, International Financial Statistics, Reserves Bank of St. Louis, OPEC annual statistics bulletin, U.S. Energy Information Administration.

Data collection procedures in this study using the literature study method or literature contained in the relevant economic journals and books supporting economic theory as a research reference. The secondary data were obtained online through the source of agencies and institutions related to this research such as Bank Indonesia, International Financial Statistics, Reserve Bank of St. Louis for countryspecific variable, U.S. Energy Information Administration and OPEC annual statistics bulletin for the world oil market.

\subsection{Analysis Technique}

The Unit root tests should be done before the estimation of the time-series data to determine whether all the variables used in the model is stationary (a stationary stochastic process) or not. Time series data is often not stationary, resulting in spurious regression or false regression. Spurious regression is indicated by statistically significant regression results, but has high R2 as well as significant t-statistics but does not have a relationship or no economic significance (Enders, 2004). The time-series data is said to be stationary if it does not contain the root (unit root) units, i.e. the mean, variance, and covariant constant over time (time-invariant) or the same on a fixed lag. On the other hand, time-series data is not stationary if it contains unit roots, i.e. mean, variance, and covariance not constant (Gujarati, 2004).

The stationarity test based on Augmented Dickey-Fuller (ADF) test revealed that the data of all variables are not stationary at the level $(\mathrm{Yt})$, to obtain stationary data can be done by differencing data. Differencing data is to reduce data period with data of previous period so that at first difference level (Yt-1) will get different data. If the time-series data from the ADF test results at the first difference level, there is no unit roots in all variables, then the data is static and can proceed to the next stage. However, when the data is not stationary at the first difference level, it is necessary to do second differencing so that the data obtained at the second difference level. If the second difference is not obtained by stationary time series data, then this phenomenon is called non-integrated.

Optimal determination of lag length (time interval) is crucial in the SVAR method because this model is susceptible to lag length. If the lag is too small, then it will not show the white noise process so the model cannot accurately estimate the actual error. If the lag is used too much, then it can reduce the ability to reject $\mathrm{H}_{0}$, because additional parameters that too much will reduce the degrees of freedom. Appropriate lag determination will result in residuals that are Gaussian, meaning free from problems of autocorrelation and heteroskedasticity (Gujarati, 2004).

The Structural VAR (SVAR) model was first used by Sims \& Bernanke (1986). This methodology analyzes the response of a variable to shock, where the Structural VAR model separates recursive elements (restricting the relationship of variables based on structural equations constructed under economic theory) to provide a restriction for separating the movement of endogenous variables concerning shock. In the general VAR model does not limit the relationship of variables because it has recursive elements (endogenous variables affect each other).

The structural VAR model is more suitable for applying economic theory, because of not all variables in the model influence each other, whether or not one variable influences the other variables according to structural equations built on economic theory. 
The Structural VAR model used in this study is a developmental variation of Sims (1986), the election of this model because of the similar characteristics of previous research objects conducted by Cunado et al. (2015) in Asian countries (India, Japan, South Korea). These countries are countries that embrace a small open economy like Indonesia. Structural VAR model in this research can be written as follows:

$A 0 x t=(L) x t-1+B \varepsilon t$

$x t=$ vector $7 \times 1$ used variable.

$A 0=$ contemporaneous relation between variable.

$(L)=$ finite-order polynomial by operator lag $\mathrm{L}$.

$\varepsilon t=$ structural shock in the form of structural disturbance vector.

$\mathrm{B}=$ impact matrix by non-zero diagonal

Restrictions in the SVAR model are formed based on related economic theory as described in the previous chapter. The framework of Structural VAR model in this study can be expressed as follows (Sims: 1986:

$\left[\begin{array}{c}\Delta L Q_{\text {oil }} \\ \Delta L Y_{w} \\ \Delta L P_{\text {oil }} \\ \Delta L G D P \\ \Delta L C P I \\ \Delta i \\ \Delta L E R\end{array}\right]=\left[\begin{array}{ccccccc}1 & 0 & 0 & 0 & 0 & 0 & 0 \\ A_{21} & 1 & 0 & 0 & 0 & 0 & 0 \\ A_{31} & A_{32} & 1 & 0 & 0 & 0 & 0 \\ A_{41} & A_{42} & A_{43} & 1 & 0 & 0 & 0 \\ A_{51} & A_{52} & A_{53} & A_{54} & 1 & A_{56} & 0 \\ 0 & 0 & A_{63} & A_{64} & A_{65} & 1 & 0 \\ A_{71} & A_{72} & A_{73} & A_{74} & A_{75} & A_{76} & 1\end{array}\right]\left[\begin{array}{c}\varepsilon_{\Delta L Q_{o l l}} \\ \varepsilon_{\Delta L Y_{w}} \\ \varepsilon_{\Delta L P_{o l l}} \\ \varepsilon_{\Delta L G D P} \\ \varepsilon_{\Delta L C P I} \\ \varepsilon_{\Delta i} \\ \varepsilon_{\Delta L E R}\end{array}\right]$

In the matrix equation above, $\varepsilon_{\triangle L Q_{\text {oil }}}, \varepsilon_{\triangle L Y_{w}}, \varepsilon_{\Delta L P P_{\text {oll }}}, \varepsilon_{\triangle L G D P}, \varepsilon_{\triangle L C P l}, \varepsilon_{\Delta L}, \varepsilon_{\triangle L E R}$ is a structural shock in the form of structural vector disturbance. In the $A(L)$ matrix Aij denotes the estimated coefficients and $L$ denotes the operator lag or the average coefficient movement for the degree of polynomial Aij (L) or optimum lag of the Structural VAR model. Variants and covariances the matrix Aij (L) bring up 27 equations to solve from a total of 49 equations in the matrix. In the Aij (L) matrix Aij denotes two interconnected shocks. If Aij shows 0 , then there is no contemporaneous effect, or both shocks do not correlate.

To determine the effect of standard deviation shock on changes in current or future endogenous variable values, measure the magnitude (change in per cent), the length of response and evaluate the impulse response method. The shock from endogenous variables has a direct effect on the variable itself, then passed on to other endogenous variables through the structural VAR model. Impulse response describes the reaction of international variables of oil shock to other variables.

VAR structural model also uses forecast analysis of error decomposition of variance or Variance Decomposition (VD) is useful to decompose the variation in one endogenous variable that will be estimated to be shock component of endogenous variables. This analysis also provides information about the importance of any random changes to the variables in the structural VAR model and the proportion of the shock effect on the shock of other variables in the present and future periods. The result of variance decomposition shows how strong the relationship of causality granger in the variable. Therefore, it can be concluded when a variable explains the strong relationship of forecast error variance of other variables. Then, this shows a strong casualty gratuity relationship.

\subsection{Model Analysis}

The Augmented Dickey-Fuller (ADF) test is performed, and the outcome is shown in Table 1.0 below. The null hypothesis $(\mathrm{HO})$ used in this method is that there is a root unit, which means that the time series data used is not stationary. The alternative hypothesis ( $\mathrm{H} 1)$ states that there is no unit root, which means the time series data used is stationary. In the ADF test, the stationary or absence of data can be seen from its statistical ADF value. The ADF test whose statistical count is smaller than the Mackinnon critical value, then $\mathrm{HO}$ is accepted, and $\mathrm{H} 1$ is rejected. Conversely, if the ADF statistic test is greater than Mackinnon critical value, then $\mathrm{H} 0$ is rejected, and $\mathrm{H} 1$ is accepted, which means the data is stationary.

Variable stationarity can be seen from the ADF t-statistic value of each variable which is smaller than the Mackinnon Critical Value value at $1 \%, 5 \%$, or $10 \%$ error rate. Besides, variable stationarity also can be detected when the value of probability is smaller than $\alpha=1 \%, 5 \%$ or $10 \%$. 
Table 1. Level Stabilization Test Result of ADF Level

\begin{tabular}{lccccc}
\hline \multirow{2}{*}{ Variable } & \multirow{2}{*}{ ADF Prob. } & ADF & \multicolumn{3}{c}{ Mackinnon Critical Value } \\
\cline { 4 - 6 } & & t-statisctic & $1 \%$ & $5 \%$ & $10 \%$ \\
\hline Produksi Minyak & 0.0836 & -3.237516 & -4.059734 & -3.458856 & -3.155470 \\
World Ec. Act. & 0.1319 & -3.021946 & -4.059734 & -3.458856 & -3.155470 \\
Harga Minyak & 0.5215 & -2.131253 & -4.059734 & -3.458856 & -3.155470 \\
GDP & 0.9002 & -1.219012 & -4.063233 & -3.460516 & -3.156439 \\
CPI & 0.8924 & -1.254935 & -4.062040 & -3.459950 & -3.156109 \\
Tingkat Diskonto & 0.0155 & -3.905965 & -4.059734 & -3.458856 & -3.155470 \\
Nilai Tukar Rupiah & 0.6260 & -1.939015 & -4.062040 & -3.459950 & -3.156109 \\
\hline
\end{tabular}

Table 1 shows that only two variables are stationary. The world oil production variables show the ADF t-statistics smaller than Mackinnon Critical Value at a critical point of $10 \%$, and the probability is smaller than $\alpha=10 \%$. The discount rate shows a smaller ADF t-statistic than Mackinnon Critical Value at a critical point of $5 \%$ and a probability smaller than $\alpha=5 \%$. In stationary tests, if there is only one variable that is not stationary at the level, it is necessary to test the root unit again at the next level, namely the first difference because there are two variables that are not stationary in the ADF test at the level.

Table 2. First Stage ADF Stationary Test Result Difference

\begin{tabular}{lccccc}
\hline \multirow{2}{*}{ Variable } & \multirow{2}{*}{ ADF Prob. } & ADF & \multicolumn{3}{c}{ Mackinnon Critical Value } \\
\cline { 2 - 6 } & & t-statistic & $1 \%$ & $5 \%$ & $10 \%$ \\
\hline Oil production & 0.0000 & -8.403734 & -4.059734 & -3.458856 & -3.155470 \\
World Ec. Act. & 0.0028 & -4.478374 & -4.060874 & -3.459397 & -3.155786 \\
Oil price & 0.0000 & -7.760422 & -4.059734 & -3.458856 & -3.155470 \\
GDP & 0.0066 & -4.203316 & -4.063233 & -3.460516 & -3.156439 \\
CPI & 0.0000 & -5.620354 & -4.062040 & -3.459950 & -3.156109 \\
Discount rate & 0.0000 & -8.090996 & -4.059734 & -3.458856 & -3.155470 \\
Currency exchange & 0.0000 & -6.305175 & -4.062040 & -3.459950 & -3.156109 \\
\hline
\end{tabular}

Table 2 shows that all variables (Qoil, Yw, Poil, Gross Domestic Product, Consumer Price Index, discount rate, rupiah exchange rate against US dollars) have an ADF t-statistic value smaller than Mackinnon critical value with a critical point $1 \%$ and the ADF probability value is smaller than $\alpha=1 \%$. Thus, all the variables in this study are stationary at the first difference level. In the SVAR test, the resulting estimation results will be significantly affected by the lag length. The shorter the lag used in this method will produce better test results because the lag that is too long will reduce the degree of freedom resulting in loss of information needed. Determine the optimal lag with some of the following criteria: Likelihood Ratio (LR), Final Prediction Error (FPE), Akaike Information Criterion (AIC), Schwarz Information Criterion (SC) and Hannah-Quin Criterion (HQ).

Table 3. Optimal Lag Test Results

\begin{tabular}{|ccccccc|}
\hline Lag & LogL & LR & FPE & AIC & SC & HQ \\
\hline 0 & 938.3040 & NA & $3.80 \mathrm{e}-18$ & -20.24574 & -20.05386 & -20.16830 \\
1 & 1823.153 & 1615.811 & $4.90 \mathrm{e}-26$ & -38.41637 & $-36.88137^{*}$ & -37.79683 \\
2 & 1919.617 & 161.4731 & $1.78 \mathrm{e}-26$ & -39.44821 & -36.57008 & -38.28657 \\
3 & 2008.482 & $135.2289^{*}$ & $7.81 \mathrm{e}-27^{*}$ & $-40.31483^{*}$ & -36.09358 & $-38.61110^{*}$ \\
\hline
\end{tabular}

Table 3 shows that not all criteria provide the same optimal lag recommendation. The optimal lag recommended by each criterion will have an asterisk (*). The LR, FPE, and AIC and HQ criteria recommend lag three as the optimal lag while the SC criterion recommends lag one as the optimal lag. In the optimal lag test results selected lag is more recommended by looking at the number of stars, most of which is lag three then the optimal lag used is lag 3. 
World oil production only significantly affects the world economic activity shown in C (1). While the relation between world oil production with the variable on the world oil market and variable in the domestic economy shows the insignificant relationship, as shown in $C(2)$ to $C$ (5). For $C$ (6) to $C$ (9) shows the relationship between global economic activity to related variables. Test results on the SVAR model show that global economic activity significantly affects the variable of world oil price $C(6)$. For the relationship between world economic activity with gross domestic product $C(7)$, consumer price index $C$ (8) and rupiah exchange rate $C(9)$ indicates an insignificant relationship.

The shock of global oil prices significantly affected two domestic variables, as indicated by the significant SVAR value of the relation between world oil price shock to GDP, C (10) and the oil price shock relation to the exchange rate of $C(13)$. In comparison, the other two domestic variables of oil price shock relation to CPI C (11) and discount rate C (12) showed insignificantly.

The relationship between variables in the domestic economy shown in $C(14)$ to $C(20)$ indicates most significant. C (14) to C (16) shows the relationship between the effect of changes in GDP on CPI, discount rate and rupiah exchange rate. The relation of GDP to the discount rate shown in C (15) shows an insignificant relationship. In contrast, the GDP relationship to CPI and the rupiah exchange rate shows a significant negative relationship. The relationship between $\mathrm{CPI}$ and the exchange rate shows a significant negative result shown in $\mathrm{C}(18)$ while the relationship with the discount rate indicates a significant negative. Discount rates affect $\mathrm{CPI}$, and the exchange rate is statistically not significantly positive, as seen in C (19) and $C(20)$.

\section{Discussions}

Since the 1970s, oil is known not only to affect the energy market conditions but also to be one of the causes of fluctuations in the domestic economy. Macroeconomists studying world oil prices see that changes in oil prices in the world oil market are one of the causes of economic fluctuations (Baumeister et al., 2009).

Oil prices in the world oil market are heavily influenced by demand and supply variables. In the SVAR estimation results, world oil production (Qoil) variables that projected oil supply showed an insignificant positive relationship of 0.663276 . While for the variable of world economic activity ( $\mathrm{Yw}$ ) shows the positive relationship is not significant equal to 0.174407 . This coefficient indicates that any increase in Qoil and $Y_{w}$ variables by one per cent will affect the rising oil prices in the world oil market by 0.663276 per cent and 0.174407 per cent. The positive impact of oil supply on oil prices is because the supply curve of oil has a perfectly elastic slope, so that when increased oil supply will shift the supply curve upwards and when the demand curve remains, the oil price will increase. A positive relationship between oil demands projected to use world economic activity $(\mathrm{Yw})$ with world oil price according to demand theory. Demand theory mentions when there is an increase in demand other than due to price and supply will still result in shifts the demand curve to the top right and increase the price.

SVAR results also show the coefficient of oil production (Qoil) affects the negative activity of the world economy $(\mathrm{Yw})$, which is a projection of oil demand of -1.305442 . This means that when an increase in oil production will affect the decline in global economic activity of 1.305442 per cent. In the previous explanation, it is stated that the world oil supply curve has a perfectly elastic slope. When an increase in the supply of oil (Qoil) shifts the supply curve upwards, and as the oil demand curve does not shift it will lead to an increase in the price of oil (Poil) and reduce the demand projected through the world economic activity $(Y w)$.

The domestic economic response to the shock of oil prices in the short horizon can be seen from the IRF results. Many countries worry about the impact of changes in world oil prices on the country's domestic economy because oil prices have affected GDP fluctuations (Voon, 2009). Indonesia's GDP response to the shock of world oil prices is positive at the beginning of the period then returns to the balance line in the long term. The positive GDP relationship to oil price shocks was caused at the beginning of the period used in the study; Indonesia is a net exporter of oil so that rising oil prices will positively impact on GDP. This is consistent with the theory of the goods market on the Mundell-Fleming model $(Y=C+I+G+N X)$ where GDP is positively related to net exports. For oil exporters, oil price increases in the world oil market will increase real incomes through greater export value. This positive relationship is also supported by previous 
research conducted by Cunado et al. (2015) which mentions a positive relationship between the shock of world oil prices and GDP on net exporter countries.

In 2003 where Indonesia became a net importer of oil, it appears that the GDP response showed a negative relationship. This indicates that when a shock occurs in world oil prices, Indonesia's GDP will decline. Rising oil prices in the world oil market will be followed by rising oil prices in the domestic energy market. This is under the theory of international trade which shows that Indonesia is a small open economy country, which means the price changes in the world market will relatively affect the price of oil in the domestic market. For net oil importer countries using oil as one input in production activities, changes in oil prices in the domestic energy market will affect the supply aggregate curve. In the long run, where the response showed leads to the equilibrium line, changes in the aggregate supply curve in the domestic market are not influenced by the price level. Still, they are influenced by factors of production such as capital, labor, resources and technology. The negative relationship between GDP and oil price shocks in net oil importer countries is supported by previous research conducted by Voon (2009) and Cunado et al. (2015).

CPI can be used to measure price stability in a domestic economy. When the price level rises will lead to price changes from the supply side. Increasing the price of oil as one of the production input causes the production cost and the price in the domestic market to increase. The additional costs incurred by the price increase must be paid by the manufacturer's decision to reduce the amount of production. At a time when oil price shocks emerge, consumers will reduce consumption spending on non-energy goods to compensate for increased costs in the domestic energy market.

CPI's response to oil price shocks on the oil market shows a negative relationship in immediate response. In the second period shows the CPI response is at its highest point, which then decreases in the next period until it returns to the balance line in the long run. This negative relationship means that when world oil prices increase, consumer price (CPI) decreases. This is also true of Sakashita \& Yoshizaki (2016) research. In this study, impulse response results in developing countries (Brazil, India, and Mexico) for CPI response to world oil price shocks showed negative results. This is due to the existence of government price regulation on oil-related goods. In demand and supply theory, when the government implements price regulation, the price level on the oil market can be maintained. Still, the government will bear the excess prices that consumers should accept.

The discount rate is a projection of the monetary policy taken by the domestic government due to the economic turmoil arising from the shock of oil prices. In the IRF results for the shock of the discount rate can also be seen whether the model under test is a price puzzle and exchange rate puzzle which generally appear on the VAR method. The impulse response of the world oil price shock to the discount rate shows a negative relationship in the immediate response. This means that when the world oil price shock occurs, it will respond with the decreasing of the discount rate determined by Bank Indonesia. This negative relationship is caused by the negative relationship of CPI to the shock of oil prices. In discount rate theory, this policy serves as a tool that can be used by Bank Indonesia as monetary policy in regulating the price level on the domestic economy. This can be seen through the impulse response of CPI shock to the discount rate showing a positive relationship. The negative relationship between oil price shock and the discount rate is supported by previous research conducted by Cunado et al. (2015).

According to IRF results, it shows that in the model in this study, there is no price puzzle and exchange rate puzzle. In the CPI response to the shock, the discount rate shows a negative response. This suggests that an increase in the discount rate (contractionary monetary policy) will be responded to a fall in the price level (CPI) in the domestic market. While the exchange rate puzzle is also not shown on the response of the rupiah exchange rate to monetary policy shock (i). The rupiah exchange rate response shows a negative (appreciation) to the monetary policy shock, indicating that when the government implements a contractionary monetary policy, it will respond with the appreciation of the rupiah exchange rate. The exchange rate is one factor in measuring the level of a country's domestic economy compared to other countries. The role of the exchange rate can describe the level of trade of a country that is important for economic activity in the free market. Samuelson (2010) explains that the exchange rate is the price of one unit of foreign currency in the domestic currency, or it may also mean the price of the domestic currency against the foreign currency. 
Like CPI and discount rate, the effect of world oil price shock on the rupiah exchange rate on shorthorizon is negative. This means that when the oil price increases, it will be responded by the appreciation of the rupiah exchange rate. This response is due to the position of the Indonesian state as a net exporter of oil. Based on exchange rate theory, Simorangkir \& Suseno (2004) mentioned factors that affect the exchange rate, one of which is the balance of payments. If the balance of payments has a surplus, then the exchange rate will strengthen (appreciation) and if the balance of payments has a deficit, then the exchange rate will weaken (depreciation). This result is also supported by previous research conducted by Cunado et al. (2015) which mentions to net exporter countries. The exchange rate will respond negatively (appreciation) when there is a shock to world oil prices.

Table 4. Impulse Response Function Variable Non-Restricted Results

\begin{tabular}{|c|c|c|c|c|c|c|c|}
\hline Respond & \multicolumn{7}{|c|}{ Shock } \\
\hline & Qoil & Yw & Poil & GDP & CPI & i & ER \\
Qoil & $\mathrm{A}:+$ & 0 & 0 & 0 & 0 & 0 & 0 \\
Yw & $\mathrm{A}:+$ & $\mathrm{A}:+$ & 0 & 0 & 0 & 0 & 0 \\
Poil & $\mathrm{A}:+$ & $\mathrm{A}:+$ & $\mathrm{A}:+$ & 0 & 0 & 0 & 0 \\
GDP & $\mathrm{A}:-$ & $\mathrm{A}:+$ & $\mathrm{A}:+$ & $\mathrm{A}:+$ & 0 & 0 & 0 \\
CPI & $\mathrm{A}:-$ & $\mathrm{A}:+$ & $\mathrm{A}:-$ & $\mathrm{A}:+$ & $\mathrm{A}:+$ & $\mathrm{A}:-$ & 0 \\
i & 0 & 0 & $\mathrm{~A}:-$ & $\mathrm{A}:+$ & $\mathrm{A}:+$ & $\mathrm{A}:+$ & 0 \\
ER & $\mathrm{A}:-$ & $\mathrm{A}:-$ & $\mathrm{A}:-$ & $\mathrm{A}:+$ & $\mathrm{A}:+$ & $\mathrm{A}:-$ & $\mathrm{A}:+$ \\
\hline
\end{tabular}

Table 4 shows a variable response to the shock of the relevant variable. The amount of shock contribution of a variable will influence related variables almost the majority in this study at the beginning of the period showed the largest contribution comes from the variable itself except the discount rate variables. At the discount rate variable at the beginning of the period shows the largest contribution comes from the CPI variable. This indicates that at the beginning of the variable period, the discount rate is affected by the CPI shock of $65.18 \%$. For long-term on a variable, the shock variable for the variable itself is decreasing. Still, it gives the largest contribution except for CPI and discount rate wherein the long term the biggest contribution is from the rupiah exchange rate (ER).

\section{Conclusions}

Based on the results of data analysis and discussion, then the conclusions that can be taken from this study as follows:

1. The shock of world oil prices has a positive impact on GDP.

2. The shock of world oil prices negatively impacts the $\mathrm{CPI}$, discount rate, and rupiah exchange rate. 3. There is an absence of price puzzle and exchange rate puzzle on impulse response variable price level (CPI) and exchange rate (ER) against the shock of discount rate.

\section{Suggestions}

Based on the above conclusions, the authors provide advice under the results of this study, as follows:

1. The future researcher is expected to add domestic variables to show more detailed domestic conditions and to see how between variables affect each other. The addition of countries for observation is also expected to be added to compare how a country responds to world oil prices compared to other countries.

2. The positive impact of the oil price shock on GDP is the impact that Indonesia positions as a net exporter of oil. However, seeing Indonesia as an oil importer country, the government should pay attention to the negative impact of oil price shock. The negative impact of global oil price shocks on GDP can be reduced by increasing government subsidy spending and redirection to productive sectors and tax reductions in export business to increase the balance of payments and investments and boost the amount of national output or income. 
3. Indonesia's oil consumption which has become an increasingly oil importer net country needs to be anticipated by saving the use of oil and diverting the use of oil to alternative energy sources to reduce dependence on one energy source. In the end, it will reduce consumption to oil and lower the negative impact of CPI on the shock of world oil price.

4. The appreciation of the rupiah exchange rate against the shock of world oil prices is undoubtedly good for the import-oriented economy, but this will weaken export-oriented domestic companies. The government should keep it.

\section{References}

1. Baumeister, C., Peersman, G. (2010). Sources of the Volatility Puzzle in the Crude Oil Market. Ghent University Working Paper, No. 2010/634

2. Bernanke, B. S. (1986). Alternative Explanations of the Money Income Correlation. CarnegieRochester Conference Series on Public Policy. 1986: 49-100.

3. Dornbusch, R. (2008). Makroekonomi, Jakarta: Penerbit Media Global Edukasi.

4. Enders, W. (2004). Applied Econometric Time Series. Second Edition. United States: J. Wiley.

5. Gujarati, D. N. (2004). Basic Econometrics. Fourth Edition. New York: McGraw-Hill.

6. Hamilton, J. D. (2003). What is an Oil Shock?. Journal of Econometrics, 113 (2003) 363-398.

7. Ichsandimas M. W., Malik, D. C. (2014). World Oil Prices and Indonesia Macroeconomic. Journal Ekonomi Pembangunan, 15 (2014): 27-33

8. Mankiw, N. G. (2009). Macroeconomics. Seventh Edition. New York: Worth Publishers.

9. Rodriguez, R. J., Sanchez, M. (2005). Oil Price Shock and Real GDP Growth: Empirical Evidence for Some OECD Countries. Applied Economics 37, 201-228.

10.Salvatore, D. (2012). International Economics. Eleventh Edition. United States: John Wiley and Sons

11.Samuelson, P. A., Nordhaus, W. D. (2010). Economics. Nineteenth Edition. Singapura: McGraw-Hill International Edition

12.Simorangkir, I., Suseno. (2005). Sistem dan Kebijakan Nilai Tukar. Bank Indonesia. Jakarta.

13.Sims, C. A. (1986). Are Forecasting Models Usable for Policy Analysis?. Federal Reserve Bank of Minneapolis Quarterly Review. 1986: 2-16.

14.Voon, J. P. (2012). Does Oil Price Shock Affect Small Open Economies? Evidence from Hongkong, Singapore, South Korea and Taiwan. Applied Economics Letters, 19(2012): 1599-1602. 